\title{
Strangers in a strange land: Ecological dissimilarity to metatherian carnivores may partly explain early colonization of South America by Cyonasua-group procyonids
}

\author{
Russell K. Engelman (D) and Darin A. Croft (D)
}

\begin{abstract}
It was once thought that the endemic carnivorous mammals of South America, the metatherian sparassodonts, were driven extinct by North American carnivorans through competitive exclusion. However, sparassodonts went extinct before most groups of carnivorans entered South America; only the endemic Cyonasua-group procyonids (Cyonasua and Chapalmalania), which immigrated to South America nearly 4 million years earlier than other carnivorans, significantly overlapped with sparassodonts in time. In this study, we examine the functional morphology of the dentition of Cyonasua and Chapalmalania through quantitative analysis to determine the dietary habits of these taxa and the degree to which they may have ecologically overlapped sparassodonts and large predatory Neogene didelphimorphians. We find Cyonasua and Chapalmalania to be more carnivorous than extant procyonids, other than Bassariscus, in agreement with previous studies, but more omnivorous than most other carnivorans and all meat-eating South American metatherians, including sparassodonts. The extreme ecological dissimilarity between Cyonasuagroup procyonids and members of the endemic South American predator guild may explain why procyonids were able to successfully establish themselves in South America several million years earlier than most other northern mammals (including all other carnivorans): they moved into a previously unoccupied ecological niche (large omnivore) and avoided direct competition with incumbent native species, a situation similar to that documented in historical cases of biological invasion. The omnivorous diets and climbing/swimming abilities of procyonids may have increased their chances for a successful over-water dispersal relative to other carnivorans, further favoring their successful establishment in South America.
\end{abstract}

Russell K. Engelman. Department of Biology, Case Western Reserve University, 10900 Euclid Avenue, Cleveland, Ohio 44106, U.S.A. E-mail: neovenatoridae@gmail.com

Darin A. Croft. Department of Anatomy, Case Western Reserve University School of Medicine, 10900 Euclid Avenue, Cleveland, Ohio 44106-4930, U.S.A. E-mail: dcroft@case.edu

Accepted: 5 August 2019

First published online: 12 September 2019

Data available from the Dryad Digital Repository: https://doi.org/10.5061/dryad.9kj2fr6

\section{Introduction}

South America hosts an impressive diversity of extant carnivorans, represented by approximately 45 species (Burgin et al. 2018). However, this high diversity is a recent phenomenon. For most of the Cenozoic, terrestrial carnivorans were not present in South America. Instead, the terrestrial carnivore guild was primarily composed of a wide variety of non-placental and nonmammalian carnivores, including several groups of metatherians (including sparassodonts; see Croft et al. 2018 and references therein; Prevosti and Forasiepi 2018 and references therein), cariamiform birds (Alvarenga et al. 2011; Degrange et al. 2012; Tambussi and Degrange 2013), and terrestrial sebecid crocodyliformes (Pol et al. 2012). It is not until the late
Miocene that fossils of terrestrial carnivoransspecifically procyonids - are found in South America. These earliest procyonids include two closely related and apparently endemic genera: Cyonasua (late Miocene-middle Pleistocene, Huayquerian to Ensenadan South American Land Mammal Ages [SALMAs]) and Chapalmalania (late early to late Pliocene, ChapadmalalanVorohuean SALMAs), hereafter referred to as the "Cyonasua group" following previous authors (e.g., Patterson and Pascual 1968; Baskin 1982; Soibelzon and Prevosti 2007; Forasiepi et al. 2014; Tarquini et al. 2016).

Cyonasua, as traditionally defined, appears to be paraphyletic relative to Chapalmalania (Baskin 2004; Forasiepi et al. 2014); Chapalmalania is first recorded in the late early Pliocene 
(Chapadmalalan SALMA) and is thought to have originated via an in situ speciation from a species of Cyonasua (Kraglievich and de Olazabal 1959; Marshall et al. 1979; Baskin 2004; Forasiepi et al. 2014). Cyonasua and Chapalmalania do not appear to be closely related to the modern radiation of South American procyonids (Forasiepi et al. 2014), and their dispersal to the continent appears to have been separate from that of other procyonid lineages which do not appear in the South America fossil record until much later (Rodriguez et al. 2013; Forasiepi et al. 2014; Prevosti and Forasiepi 2018; Ruiz-Ramoni et al. 2019). Two other genera, Parahyaenodon and Tetraprothomo, are also considered to belong to this group but are poorly distinguished from Cyonasua and are probably synonymous with this taxon (Forasiepi et al. 2007).

Cyonasua-group procyonids ranged across South America, from Venezuela and Colombia in the north (Forasiepi et al. 2014) to Argentina and Uruguay in the south (Reguero and Candela 2011; Tarquini et al. 2016; Soibelzon et al. 2019). Most specimens of Cyonasua-group procyonids come from sites of late Miocene to early Pliocene age (Huayquerian to Chapadmalalan SALMAs), but the group as a whole is last recorded during the early Pleistocene (based on the Ensenadan Cyonasua meranii; Ameghino and Kraglievich 1925; Soibelzon et al. 2008; Prevosti et al. 2013). The ancestors of Cyonasua-group procyonids reached South America by $7.3 \mathrm{Ma}$ (the age of the oldest well-dated Cyonasua-group procyonid fossil; Reguero and Candela 2011), likely by island hopping or over-water dispersal (Simpson 1950; Marshall 1981; Webb 1985; O’Dea et al. 2016; but see Montes et al. 2015), making them the earliest securely dated North American mammals to participate in the great American biotic interchange (GABI; Webb 1985; Woodburne 2010; but see Prothero et al. 2014 and references therein). Cyonasua-group procyonids were the only carnivorans in South America for nearly 4.3 Myr (until the arrival of canids and mustelids in the late Pliocene Vorohuean SALMA, 2.9 Ma; Prevosti and Forasiepi 2018) and the only ones to coexist with sparassodonts, the primary group of endemic mammalian carnivores (Forasiepi et al. 2007; Prevosti et al. 2013; Prevosti and Forasiepi
2018). Most groups of carnivorans, including felids and ursids, do not appear in the South American fossil record until the Pleistocene. However, exactly how and why Cyonasuagroup procyonids were able to establish themselves in South America nearly 4 million years earlier than other carnivorans (and long before most other groups of North American mammals) has never been examined in detail.

In this study, we test the hypothesis that ecological dissimilarity to incumbent metatherian carnivores was an important contributing factor to the early appearance of Cyonasua-group procyonids in South America. We do so by examining the functional morphology of the dentition of Cyonasua-group procyonids relative to other late Miocene-early Pliocene South American mammalian carnivores, particularly sparassodonts, and evaluating their positions in ecological morphospace. Based on this information, we reconstruct the positions of these taxa within the late Miocene-Pliocene South American predator guild and infer the degree to which there may have been ecological (specifically dietary) overlap between these groups. The results are discussed in the context of other factors that may have affected the propensity of Cyonasua-group procyonids to disperse to and establish themselves in South America.

\section{Materials and Methods}

For this analysis, we began with the mostly genus-level data set of Croft et al. (2018), which coded nearly all sparassodonts, most predatory late Neogene didelphoids, and a broad comparative sample of extant carnivorans for 16 characters describing the functional morphology of the dentition and 1 character describing body mass. To this data set, we added one new character, the number of upper molars with grinding surfaces (described later), and coded seven additional taxa: the late Neogene South American procyonids Cyonasua and Chapalmalania, FMNH P14407 (a sparassodont from the late Miocene or Pliocene of Corral Quemado, Argentina), and four extinct North American procyonids (also detailed later). This resulted in a data set of 18 characters (listed in Supplementary Table 1) and 365 taxa. Additional modifications 
to the data set of Croft et al. (2018) are described in Supplementary Table 2, and specimens examined for comparative purposes and used to add new codings and taxa are detailed in Supplementary Table 3 . The complete data set used for this study is presented in Supplementary Table 4. Following previous studies (e.g., Wesley-Hunt 2005; Prevosti et al. 2013; Croft et al. 2018; Tarquini et al. 2018b) the $\mathrm{P} 4 / \mathrm{m} 1$ of carnivorans and the penultimate upper/ultimate lower molar in non-carnivoramorphan carnivores (M3/m4 in carnivorous metatherians) were considered to be functionally analogous.

The new character developed for this analysis (18: number of upper teeth with grinding surfaces) was incorporated to more accurately reflect the functional morphology of metatherian dentitions. Examination of the parent data set found that the most strongly loaded character on the first axis was the "number of postcarnassial upper teeth" (character 14). However, this character showed strong phylogenetic signal, as the primary carnassials in metatherians are almost always $\mathrm{M} 3 / \mathrm{m} 4$, and thus in metatherians there is always one upper molar posterior to the carnassial regardless of dietary habits. Similarly, the fact that metatherians often have grinding surfaces on molars anterior to the primary carnassials (i.e., on $\mathrm{M} / \mathrm{m} 1-2$ ) were unaccounted for in the parent study. Teeth were coded having a grinding surface if there was at least one structure (e.g., protocone) that could function in occlusion.

Body-mass estimates for Cyonasua and Chapalmalania were taken from Tarquini et al. (2018a) and Prevosti and Forasiepi (2018), respectively, which can be consulted for additional information. Details of other character codings for Cyonasua and Chapalmalania are included in Supplementary Table 5.

FMNH P14407, a sparassodont specimen from the late Miocene or Pliocene of Corral Quemado, Argentina, was added to this analysis, because it appears to represent a distinct taxon from this time period. The taxonomy of this specimen is uncertain: Riggs (1934) referred it to Acrohyaenodon acutidens, whereas Marshall (1978: pp. 65-66) tentatively referred "A." acutidens to the borhyaenid genus Eutemnodus. Forasiepi et al. (2007) considered FMNH P14407 to represent an indeterminate "prothylacynine" (basal borhyaenoid). Our observations of FMNH P14407 agree with Forasiepi et al. (2007); the morphology of this specimen (including the absence of a metaconid and presence of a multicusped talonid) is more similar to that of borhyaenoids such as Prothylacynus than borhyaenids or thylacosmilids. Despite the uncertain taxonomic status of FMNH P14407, its morphology is distinct from other sparassodonts of this age. We could not examine the holotype of "A." acutidens firsthand, and whether this specimen pertains to the same taxon as FMNH P14407 is beyond the scope of this study.

Four genera of extinct North American procyonids, Arctonasua, Bassaricyonoides, Probassariscus, and Protoprocyon, were added to this analysis to better represent the diversity of Procyonidae, the focus of this study. Body masses of Protoprocyon and Probassariscus were coded based on extant, similar-sized Bassariscus spp. (Baskin 1982) and body mass of Bassaricyonoides was coded based on extant Bassaricyon (Baskin 2003). Body mass of Arctonasua was estimated at $\sim 9.5 \mathrm{~kg}$ using the occipito-orbital length regression equation of Van Valkenburgh (1990) and a measurement of $89.92 \mathrm{~mm}$ from AMNH F:AM 50054 (Arctonasua fricki; Baskin 1982).

The expanded data set was analyzed via correspondence analysis (CA) in PAST v. 3.21 (Hammer et al. 2001) following the methodology of Croft et al. (2018) and other studies of carnivore ecomorphology (Wesley-Hunt 2005; Werdelin and Wesley-Hunt 2010; Werdelin and Lewis 2013). CA has been used in these studies rather than principal components analysis because the data used here consist of a combination of both continuous (e.g., shape of canine, premolar dimensions, carnassial blade length) and discrete (e.g., shape of incisor row, number of premolars, shape of carnassial, number of molars) characters.

Missing data in correspondence analyses are typically handled via column average substitution. However, this can result in "centroid slippage" (Flannery Sutherland et al. 2019), in which incomplete taxa plot closer to the origin than they should. This can be especially problematic when more than one major clade is being analyzed, as in this study, as missing values are reconstructed using all groups, 
potentially overinflating morphological disparity and creating phylogenetically incongruous scenarios. To minimize such issues in this analysis, missing values were substituted with the clade average rather than the column (i.e., entire data set) average; specifically, separate average values were calculated manually for carnivorans, sparassodonts, dasyuromorphians, and didelphimorphians and used to fill missing values.

Institutional Abbreviations.-AMNH, American Museum of Natural History, New York, N.Y., U.S.A.; FMNH, The Field Museum, Chicago, Ill., U.S.A.; MLP, Museo de La Plata, La Plata, Argentina.

Anatomical Abbreviations.-P/p, upper and lower premolars; $\mathrm{M} / \mathrm{m}$, upper and lower molars.

\section{Results}

The results of the CA (Fig. 1) broadly resemble those of previous studies (Wesley-Hunt 2005; Werdelin and Wesley-Hunt 2010; Werdelin and Lewis 2013; Croft et al. 2018). The first axis (CA 1), representing $41.5 \%$ of the total variation, generally correlates with diet, with hypocarnivores exhibiting highly positive values and hypercarnivores generally exhibiting highly negative values. The second axis (CA 2), representing $16.0 \%$ of the total variation, correlates most strongly (negatively) with body mass, the angle of upper carnassial cusps in occlusal view, and, to a lesser extent (positively), with the number and robustness of premolars (Fig. 2). The first two axes represent 57.5\% of the total variation. A complete list of axis eigenvalues and taxon scores can be found in Supplementary Tables 6 and 7, respectively.

Both Cyonasua and Chapalmalania have high CA 1 values and low CA 2 values (Cyonasua: 1.394, -1.305; Chapalmalania: 1.293, -2.832) and plot farther from extant procyonids than other extinct members of this group. On CA 1, Cyonasua and Chapalmalania plot within the range of values spanned by extant procyonids (Fig. 1), between Bassariscus and all other extant species. By contrast, Cyonasua and Chapalmalania score more negatively on CA 2 than extant procyonids and fall outside the convex hull of morphospace occupied by extant members of this group. The more negative positions of
Cyonasua and Chapalmalania on CA 2 are likely due to size; this is the only character for which the scores of Cyonasua or Chapalmalania are outside the range of extant procyonids, and body mass is the character most strongly correlated (negatively) with CA 2 (Fig. 2).

Cyonasua plots in an area occupied by various extant hypocarnivores, including ursids, mephitids (e.g., Conepatus spp.), mustelids (e.g., Meles and Taxidea), and the extant binturong (Arctictis binturong) (Fig. 1). Chapalmalania plots just within the morphospace of extant ursids, to the right of non-hemicyonine ursids that are known or have been considered to have more predatory habits (Agriotherium, Arctodus, Ursus maritimus) and to the left of more omnivorous ursid species (Ursus spp. other than U. maritimus, Melursus ursinus, Tremarctos ornatus). The four extinct North American procyonids added for this analysis plot close to extant species; Bassaricyonoides, Probassariscus, and Protoprocyon plot between Bassariscus and all other extant procyonids, whereas Arctonasua plots close to Procyon pygmaeus and other extant species.

The new character added for this study (character 18) resulted in sparassodonts being more widely distributed on CA 1 than in the analysis of Croft et al. (2018). Similarly, didelphimorphians plot more positively on CA 1 than in Croft et al. (2018), close to canids such as Vulpes spp. and Urocyon spp. Sparassodont morphospace can generally be described as a relatively narrow band that spans the lower left, upper left, and a small portion of the upper right quadrants of Figure 1, with higher CA 1 values generally correlating with higher CA 2 values. Nevertheless, four main clusters of sparassodonts can be identified (see Supplementary Fig. 2) that correlate with decreasing specializations for carnivory: (1) Proborhyaena and Paraborhyaena (Proborhyaenidae) plus Australohyaena and Arctodictis (Borhyaenidae), which show the greatest specializations for carnivory and are adjacent to felid morphospace; (2) other highly specialized carnivorous borhyaenoids (Prothylacynus, Thylacosmilidae, remaining proborhyaenids and borhyaenids), in an area of morphospace sparsely populated by carnivorans but including hyaenids and the euplerid Cryptoprocta; (3) remaining borhyaenoids (e.g., Lycopsis), larger hathliacynids such 


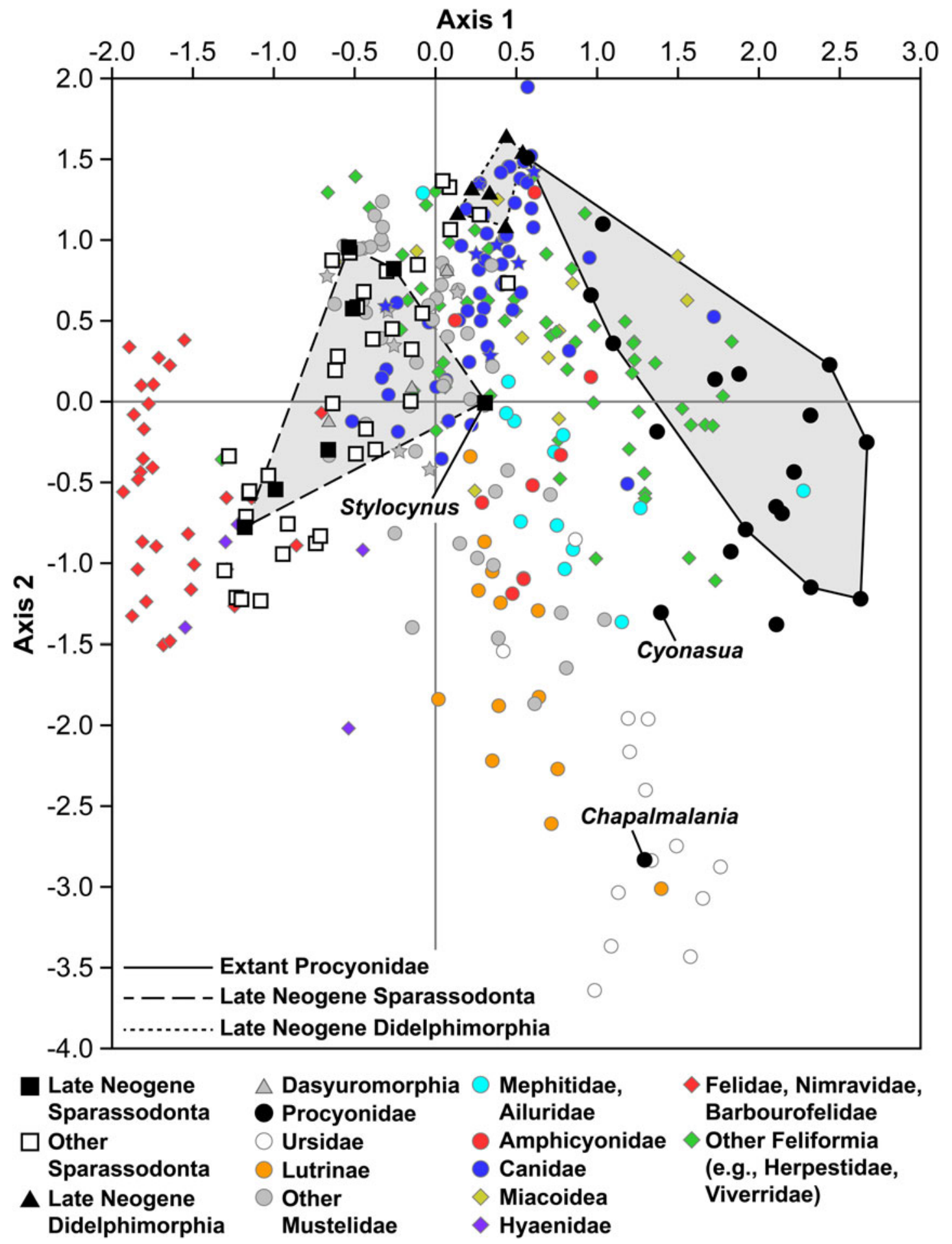

FIGURE 1. Plot of the first two axes of the correspondence analysis of all taxa used in this analysis. Carnivoran placentals are represented by circles and diamonds (caniformians and feliformians/miacoids, respectively). Cerdocyonin canids, ictonychine mustelids, and Eira are denoted by stars (see "Discussion"). 


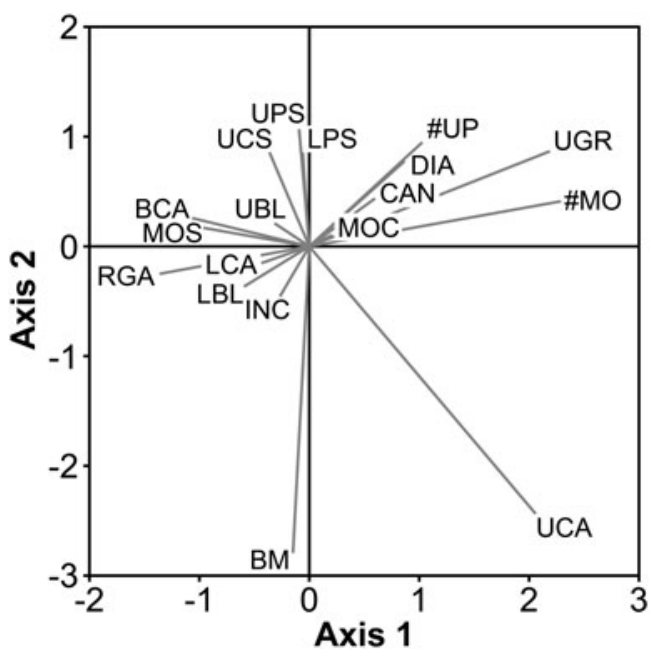

FIGURE 2. Vector plot of the eigenvalues of the first two axes for the 18 characters used in the correspondence analysis, showing the extreme negative weight of body mass (BM) on axis 2. Abbreviations: BCA, angle of lower carnassial cusps in buccal view; BM, body mass; CAN, shape of upper canines; DIA, presence of diastemata among upper premolars; INC, shape of upper incisor row; LBL, lower carnassial relative blade length; LCA, angle of lower carnassial cusps in occlusal view; LPS, shape of last lower premolar anterior to carnassial; \#MO, number of upper molars; MOC, shape of cusps of first upper molar; MOS, shape of first upper post-carnassial tooth; RGA, relative grinding area of lower molars; UBL, upper carnassial relative blade length; UCA, angle of upper carnassial cusps in occlusal view; UCS, shape of upper carnassial; UGR, number of upper teeth with grinding surfaces; \#UP, number of upper premolars anterior to the carnassial; UPS, shape of last upper premolar anterior to carnassial.

as Cladosictis and Acyon, and some smaller hathliacynids such as Notogale and all late Neogene taxa, occupying a region alongside hypercarnivorous mustelids (Gulo, Mellivora, Mustela) and hypercarnivorous canids (e.g., Aelurodon, Canis lupus); and (4) smaller sparassodonts (e.g., Pseudonotictis, Patene, Sipalocyon, Perathereutes) in an area mostly occupied by canids at the threshold between mesocarnivory and hypercarnivory (e.g., Vulpes velox, Pseudalopex culpaeus, Pseudalopex griseus). The basal sparassodonts Hondadelphys and Stylocynus are outliers and plot more positively on CA 1 than other sparassodonts. Late Neogene sparassodonts cluster into three widely spaced groups: larger borhyaenoids (Thylacosmilus, Borhyaenidae indet., and FMNH P14407), the former two plotting within group 2 and the third in between groups 2 and 3; small hathliacynids (Borhyaenidium, Notictis, and Notocynus), which all fall within group 3; and Stylocynus, which as mentioned earlier, is an outlier to all of the groups listed above. It is possible the well-defined separation between groups observed here is an artifact of binning the data and that the actual separation between taxa may be more of a gradient.

There is almost no overlap among late Neogene sparassodonts, didelphimorphians, and procyonids, except for the procyonid Bassariscus astutus, which plots close to Didelphis but is not within didelphimorphian morphospace. This position may be due to the fact that smaller animals seem to cluster together regardless of dietary habits, which may be due to how the algorithm used by PAST analyzes the data, or may reflect smaller mammals with disparate habits being more generalized in morphology than larger ones. There is some overlap between didelphimorphian and sparassodont morphospace, but sparassodonts and didelphimorphians in this region do not overlap temporally (the sparassodonts are Paleogene or early Miocene taxa like Pseudonotictis or Patene). Small-bodied late Neogene taxa (e.g., Borhyaenidium, Notocynus) are positioned more distantly in morphospace.

Neither Cyonasua nor Chapalmalania are close to the morphospace occupied by didelphimorphians or late Neogene sparassodonts (or the area occupied by Sparassodonta as a whole, for that matter). Among sparassodonts, the late middle Miocene Hondadelphys plots closest to Procyonidae. Stylocynus, the sparassodont genus often considered to have been most similar to Cyonasua and Chapalmalania in its habits (Marshall 1977; Prevosti et al. 2013; Prevosti and Forasiepi 2018), does not plot close to these genera in our morphospace analysis, though it does plot closer to Cyonasua-group procyonids than any other sparassodont. Instead, Stylocynus plots near the origin, close to several mesocarnivorous or hypercarnivorous carnivorans such as Canis lupus, Chrysocyon brachyurus, and Spilogale spp.

\section{Discussion}

Dietary Habits of Cyonasua-Group Procyonids.-Overall, the positions of Cyonasua and Chapalmalania in the CA suggest that these 
taxa were hypocarnivores more specialized for carnivory than most living procyonids, in agreement with previous studies (Berman 1994; Soibelzon 2011; Reyes et al. 2013); Cyonasua and Chapalmalania plot to the left of large-bodied procyonids such as Nasua and Procyon on CA 1 , suggesting more carnivorous habits, but to the right of the extant Bassariscus, among other hypocarnivores (e.g., ursids). Omnivorous habits are supported by the gross morphology of the dentitions of Cyonasua and Chapalmalania, which show well-developed grinding surfaces and little development of shearing features compared with most carnivorans. The only nonhypocarnivores that plot close to Cyonasua and Chapalmalania are otters (e.g., Enhydra, Aonyx) and polar bears (U. maritimus); otters tend to have well-developed crushing features on their molars related to their consumption of hardshelled invertebrates, and polar bears show few dental specializations for carnivory (Sacco and Van Valkenburgh 2004; Oldfield et al. 2011), likely due to their unusual pinnipedheavy diet (Oldfield et al. 2011) and their relatively recent divergence from the omnivorous brown bear (Ursus arctos) (Lindqvist et al. 2010). It is unlikely that the well-developed grinding surfaces of Cyonasua and Chapalmalania are adaptations for specialized bone- or hard object-feeding diet (although there is evidence of scavenging behavior by Chapalmalania; Reyes et al. 2013), as the teeth of both Cyonasua and Chapalmalania are relatively small in relation to body and skull size (Prevosti and Forasiepi 2018; Tarquini et al. 2018a). Relatively small teeth are unexpected for a durophagous specialist but are seen in some extant frugivores (Kay 1975; Gingerich and Smith 1985; Strait 1993).

The positions of Cyonasua and Chapalmalania on CA 1 fit the prediction of Werdelin and Wesley-Hunt (2010) that the large gap between Bassariscus spp. and other extant procyonids in their morphospace analysis is the result of the extinction of procyonids of intermediate dental morphology. Cyonasua and Chapalmalania partially fill this gap, at least on CA 1 , which supports this idea. Additionally, three of the four fossil North America procyonids added to this analysis, Protoprocyon, Probassariscus, and Bassaricyonoides, plot between Bassariscus and all other extant procyonids.
Cyonasua and Chapalmalania also exhibit a mosaic of character codings relative to other procyonids, with some features (e.g., incisor row shape, upper carnassial relative blade length, relative grinding area) more closely resembling Bassariscus and others (shape of the upper carnassial, lower carnassial relative blade length) more closely resembling "typical" procyonids such as Bassaricyon, Procyon, and Nasua. Although Cyonasua and Chapalmalania plot outside the morphospace occupied by extant procyonids, this is mainly due to their larger size; changing the body-mass codings for Cyonasua and Chapalmalania to state 1 $(<1.5 \mathrm{~kg}$, similar to Bassariscus) results in these two taxa plotting just outside extant procyonid morphospace rather than far from it. The fact that Chapalmalania plots within the ursid morphospace is not surprising, given that this species has often been considered to be morphologically and ecologically similar to this group (Kraglievich and Olazabal 1959; Forasiepi et al. 2014).

Competition between Cyonasua-Group Procyonids and South American Metatherians.-It was once thought that the endemic South American carnivores, particularly the sparassodonts, were driven to extinction by competition with Northern Hemisphere carnivorans during the GABI (Simpson 1950, 1980; Patterson and Pascual 1968; Marshall 1976; Werdelin 1987). However, it has become apparent in recent years that there was little temporal overlap between sparassodonts and carnivorans; most sparassodonts are not recorded in the same intervals as their purported Northern Hemisphere replacements, making hypotheses of competitive displacement unlikely (Marshall 1977; Forasiepi et al. 2007; Prevosti et al. 2013; Prevosti and Forasiepi 2018). Competition between didelphimorphians and sparassodonts is still an open question, though most studies have suggested ecological partitioning and passive replacement of small sparassodonts by didelphimorphians in the Neogene (Engelman and Croft 2014; Zimicz 2014; but see Beck and Taglioretti 2019). This is supported by the results of this study; there is no overlap among late Neogene sparassodonts and didelphimorphians, but late Miocene-Pliocene didelphimorphians do overlap Paleogene-early Miocene sparassodonts. 
Cyonasua and Chapalmalania are the only South American carnivorans currently known to overlap sparassodonts in time and may have been the only terrestrial carnivorans to directly interact with them. It has been suggested that significant competitive interaction may have occurred between Cyonasua-group procyonids and some sparassodonts, particularly the genus Stylocynus (Marshall 1977; Soibelzon 2011; Prevosti et al. 2013; Engelman and Croft 2014), due to similar habits and these animals overlapping in time. Cyonasua and Chapalmalania are positioned very far from the morphospace occupied by South America metatherians (Didelphimorphia and Sparassodonta), which suggests little to no ecological overlap with these groups (Fig. 1), in agreement with most previous studies. Although the degree to which sparassodonts were omnivorous has been debated (Marshall 1977; Prevosti et al. 2013; Croft et al. 2018), virtually all authors agree that no South American metatherian (sparassodont or didelphimorphian), with the possible exception of Stylocy$n u s$, was as omnivorous as extant procyonids or ursids. However, even Stylocynus plots outside the hypocarnivore morphospace occupied by Ailurus, procyonids, and ursids (as well as Cyonasua-group procyonids), closer to mesocarnivorous or even hypercarnivorous taxa such as Canis lupus, Chrysocyon brachyurus, and Spilogale spp. Prevosti et al. (2013) considered Stylocynus to be hypocarnivorous based on relative grinding area but did not exclude the possibility of a mesocarnivorous diet. The results of this analysis and Croft et al. (2018) support the idea of a more mesocarnivorous diet for Stylocynus.

The specific ways in which the dentitions of Stylocynus and Cyonasua-group procyonids differ from one another give some insight into how these animals' diets may have differed. Cyonasua-group procyonids have more robust premolars than Stylocynus and upper carnassials with blunt cusps that are well built for crushing (Fig. 3). By contrast, the premolars of Stylocynus are labiolingually narrower and have much smaller posterobasal heels than Cyonasua-group procyonids. Similarly, the molars of Stylocynus have well-developed paracristids and tall trigonid cusps, particularly on

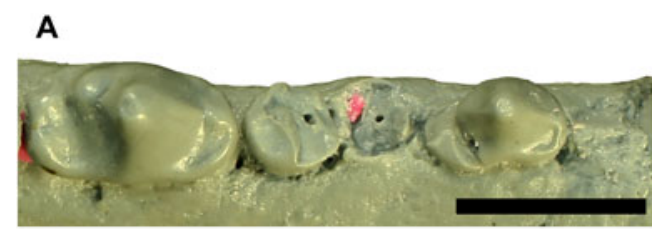

B
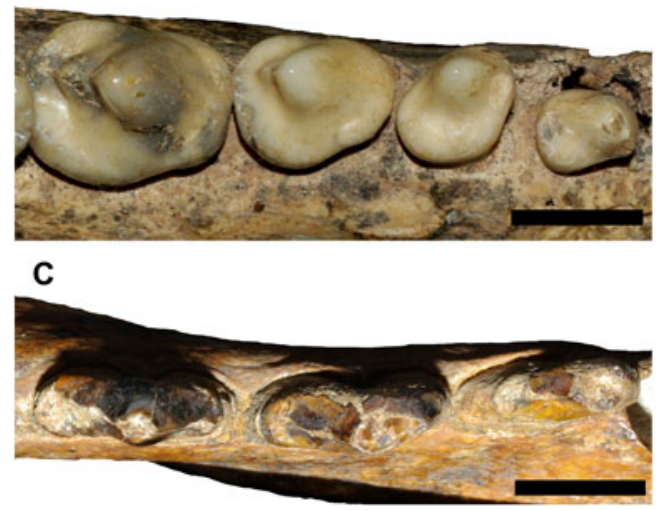

FIGURE 3. Lower premolar rows of Cyonasua-group procyonids and Stylocynus (left p1-4 and p1-3, respectively) in occlusal view, showing the more robust lower premolars of Cyonasua-group procyonids and more sectorial teeth of Stylocynus. A, Cyonasua lutaria (AMNH 117419); B, Chapalmalania altaefrontis (MLP 91-VI-5-1); C, Stylocynus paranensis (MLP 41-XII-13-1112, reversed). Anterior is to the right. Scale bar, $10 \mathrm{~mm}$.

m3-4 (Fig. 4), whereas the lower carnassial of Cyonasua-group procyonids (the functionally equivalent tooth) has almost no blade at all and a trigonid that is only slightly more prominent than that of Nasua and Procyon. The mandibular symphysis of Cyonasua-group procyonids is also less extensive and more vertical than in Stylocynus; in both Cyonasua and Chapalmalania the symphysis ends at the $\mathrm{p} 1 / 2$ embrasure and is dorsoventrally much taller than anteroposteriorly long, whereas in Stylocynus the symphysis ends below the anterior root of p3 and is anteroposteriorly much longer than dorsoventrally tall. However, the surface of the symphysis of Cyonasua-group procyonids is much more rugose than that of Stylocynus, in which it is smooth (state $2 / 3$ vs. state 1 of Scapino [1981]). The morphology of the symphysis in Cyonasua-group procyonids appears to be an apomorphy; the mandibular symphysis is unfused and smooth in most extant procyonids aside from Potos and Procyon (Scott et al. 2012). These features suggest that, even though procyonids may have had more ecological overlap 

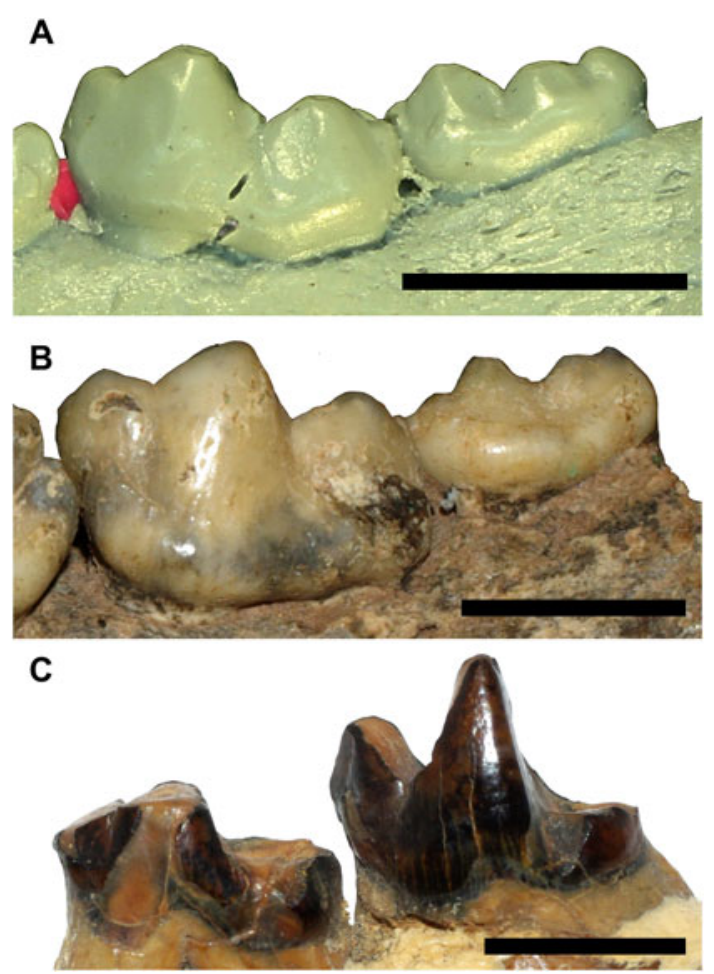

FIGURE 4. Posterior molars of Cyonasua-group procyonids and Stylocynus (left m1-2 and m3-4, respectively) in lateral view, showing the well-developed trigonid and paracristid in Stylocynus compared with the more bunodont morphology in procyonids. The $\mathrm{m} 1$ of carnivorans and the $\mathrm{m} 4$ of meat-eating metatherians are generally considered to be functionally analogous teeth. A, Cyonasua lutaria (AMNH 117419); B, Chapalmalania altaefrontis (MLP 91-VI-5-1); C, Stylocynus paranensis (MLP 11-94). Anterior is to the left. Scale bar, $10 \mathrm{~mm}$.

with Stylocynus than other sparassodonts, they occupied distinct ecological niches; Stylocynus was more specialized for feeding on meat (likely mesocarnivorous), whereas Cyonasuagroup procyonids were more specialized for feeding on other foods, such as fruit, vegetation, and invertebrates (hypocarnivorous).

Cyonasua-group procyonids and Stylocynus apparently also differed from one another in body mass, which would have further reduced competition (Prevosti et al. 2013; Prevosti and Forasiepi 2018). Body mass plays an important role in resource partitioning in modern carnivores, with larger species generally being dominant in competitive interactions (Creel and Creel 1996; Palomares and Caro 1999; Linnell and Strand 2000). The mass of Cyonasua is generally estimated at $16-21 \mathrm{~kg}$ (though at least one larger individual has been noted; Tarquini et al. 2018a), whereas Stylocynus was probably at least one-third larger $(28-35 \mathrm{~kg}$; Croft et al. 2018; Prevosti and Forasiepi 2018), and even larger individuals have been documented (e.g., MLP 41-XII-13-1112 appears to belong to a larger individual than MLP 11-94, the specimen from which most body-mass estimates of Stylocynus have been calculated; Marshall 1979). The disparity in body size (Hutchinson's ratio) between Cyonasua and Stylocynus is at minimum 1.33, which is above the critical threshhold of similarity for ecological coexistence between similar taxa (usually considered to be 1.3 or less; Hutchinson 1959; Tambussi and Degrange 2013), suggesting these animals were not direct competitors. Chapalmalania was far larger than both Cyonasua and Stylocynus, with a body mass estimated at 120-180 kg (Prevosti and Forasiepi 2018), but this taxon is first recorded approximately 2 million years after the last record of Stylocynus (Prevosti et al. 2013), suggesting that these taxa may not have overlapped in time. The new evidence presented here reinforces conclusions of previous studies that competitive exclusion was not a significant factor in the extinction of the Sparassodonta (e.g., Marshall 1977; Forasiepi et al. 2007; Prevosti et al. 2013; Engelman and Croft 2014; Zimicz 2014; López-Aguirre et al. 2017; Croft et al. 2018; Prevosti and Forasiepi 2018).

Colonization of South America by CyonasuaGroup Procyonids. - Why Cyonasua-group procyonids were able to colonize South America long before most other groups of carnivorans remains an unanswered question in studies of the GABI. This colonization is even more unusual in that the oldest record of Cyonasuagroup procyonids dates to the late Miocene, when the endemic carnivore guild of South America was ecologically diverse (Vizcaíno and De Iuliis 2003; Tambussi and Degrange 2013; Zimicz 2014; Prevosti and Forasiepi 2018) and theoretically more robust to invasion, whereas the arrival and diversification of other carnivorans appears to postdate a late Pliocene collapse of the native carnivore guild (including the extinction of the Sparassodonta), resulting in low carnivore diversity and many open ecological niches during the late Plioceneearly Pleistocene (Van Valkenburgh 1991; 
Vizcaíno et al. 2004; Forasiepi et al. 2007; Mitchell et al. 2016; Prevosti and Forasiepi 2018).

One possible explanation for the apparent early dispersal of Cyonasua-group procyonids to South America relative to other carnivores is that this is an artifact of the fossil record. In support of this idea, it been suggested (based on genetic evidence) that some other groups of carnivorans (i.e., non-Cyonasua-group procyonids such as Nasua and some mustelids like Galictis and Pteronura) colonized South America in the middle or late Miocene (Koepfli et al. 2007; Eizirik 2012). Although such a scenario cannot be ruled out completely, it seems quite unlikely based on the current fossil record. Several well-studied middle to late Miocene sites are known from equatorial South America (e.g., Acre, La Venta, Urumaco) and represent a diversity of paleoenvironments, some of which preserve the remains of small, arboreal mammals similar to small procyonids (e.g., bats, platyrrhine primates, and didelphids; Czaplewski 1996; Fleagle et al. 1997; Goin 1997). La Venta is particularly noteworthy in this regard; located only about 600 $\mathrm{km}$ from the Panamanian Isthmus, it is among the most heavily sampled fossil sites in South America (Kay et al. 1997 and references therein) and has yet to produce any remains of terrestrial North American mammal groups. It is highly unlikely that Cyonasua-group procyonids (or any North American mammals for that matter) were present in South America at the time this locality's sediments were deposited ( 13-12 Ma; Flynn et al. 1997).

There is no evidence of non-Cyonasua-group procyonids in South America before the late Pliocene. By contrast, 39 specimens of Cyonasua-group procyonids are known from this interval (Prevosti and Forasiepi 2018; Soibelzon et al. 2019), including specimens from lowlatitude sites (Forasiepi et al. 2014). Thus, the absence of other carnivorans during this interval is not simply a preservation bias against carnivores or carnivorans or a restricted geographic or ecological distribution of Cyonasua-group procyonids. Assuming Cyonasuagroup procyonids were the earliest carnivorans to successfully colonize South America, the question becomes why these animal succeeded when other carnivorans did not.
Carnivorans in general are considered to be poor over-water dispersers compared with other mammals (Meiri et al. 2004: pp. 474475; Lyras et al. 2010), with most extant island carnivorans representing populations on continental islands that became isolated by rising sea levels at the end of the last ice age (rather than dispersing over water to these locations) or, perhaps, were introduced by humans (e.g., Urocyon littoralis; Rick et al. 2009). However, several aspects of procyonid ecology suggest that they may be better over-water dispersers than most other carnivorans. First, nearly all known procyonids, both living and extinct, have at least some climbing or grasping ability (Tarquini et al. 2017), which might increase their chances of being swept out to sea on a floating tree or a mat of vegetation. Second, strong swimming abilities might further increase the chances of a procyonid successfully making it to shore in a chance over-water dispersal. Raccoons (Procyon spp.) are strong swimmers (Bigler et al. 1981; Zeveloff 2002) and coatis (Nasua spp.) have also been reported to swim (Gompper 1997). Third, the opportunistic (omnivorous) dietary habits of procyonids may have made them more likely to survive a multiday over-water dispersal event than a mammal more dependent on meat. Such habits also allow hypocarnivorous species like procyonids to exist at greater population densities than mesocarnivores or hypercarnivores. For example, in their analysis of Neotropical mammalian community structure, Robinson and Redford (1986) found that population densities of hypocarnivorous carnivorans like procyonids and Conepatus were generally at least an order of magnitude greater than those of mesocarnivorous or hypercarnivorous taxa like Eira, Galictis, and felids. Higher population densities may have increased the probability of a sweepstakes dispersal event by a procyonid rather than another North American carnivoran. At least three island procyonid populations are considered to represent natural over-water dispersals: the Cozumel island raccoon (P. pygmaeus), the Tres Marias raccoon (Procyon lotor insularis), and the Cozumel island coati (Nasua narica nelsoni) (Helgen and Wilson 2005; McFadden et al. 2008; Cuaron et al. 2009). The Tres Marias raccoon demonstrates 
that procyonids are capable of dispersing over at least $25 \mathrm{~km}$ of open water, the shortest distance between the Tres Marias archipelago and the mainland during the Pleistocene (Ortiz-Ramírez et al. 2018)

In addition to dispersing to a new environment, successful colonization requires establishing a viable population. In this regard, the ecological uniqueness of procyonids relative to the endemic South American biota may have favored their establishment in South America long before other carnivores. Studies of historical invasions of extant species have found that ecological dissimilarity between the dispersing species and the species of the new community is an important predictor of successful establishment (Darwin's naturalization hypothesis; see Sih et al. 2010; Pearson et al. 2012; Azzurro et al. 2014; Skóra et al. 2015; Vidal-García and Keogh 2017). Ecological dissimilarity allows immigrant species to exploit the environment in ways that native species do not, thereby avoiding direct competition. This situation is analogous to that inferred for procyonids and metatherian carnivores in Cenozoic South America. No South American metatherian seems to have been a large ( $>1.5 \mathrm{~kg})$, specialized hypocarnivore similar to a bear, procyonid, or the modern red panda (Werdelin 1987; Wroe et al. 2004; Orcutt 2015), though some extinct armadillos may have had hypocarnivorous dietary habits similar to Cyonasua-group procyonids (e.g., Macroeuphractus; Vizcaíno and De Iuliis 2003).

The hypothesis that ecological dissimilarity played a role in the early colonization of South America by Cyonasua-group procyonids is supported by comparing the position of procyonids in the results of the CA to canids, ictonychine (= galictine) mustelids, and the mustelid Eira, three groups that likely had dispersal abilities similar to those of procyonids but did not disperse to South America until much later, after the last record of sparassodonts. Canids and ictonychines in particular are the earliest known carnivorans in South America aside from Cyonasua-group procyonids (with the earliest records dating to $\sim 2.9$ Ma; Prevosti and Forasiepi 2018) and are some of the few groups of carnivorans known to make successful dispersals over water (van der Geer et al. 2011). Procyonids plot outside sparassodont morphospace; whereas canids, ictonychines, and Eira plot within sparassodont morphospace, as would be expected if ecological dissimilarity was a factor in successful colonization.

The early appearance of procyonids in South America is probably the result of several factors. Occupation of an ecological niche distinct from those occupied by incumbent South American mammals may have been the most important factor, but several other aspects of procyonid ecology may have favored overwater dispersal. We find no evidence for significant competition between Cyonasua-group procyonids and endemic South American carnivorous mammals such as sparassodonts, in support of other studies that have suggested that the extinction of sparassodonts was due to other factors (e.g., Marshall 1977; Forasiepi et al. 2007; Prevosti et al. 2013; Engelman and Croft 2014; Zimicz 2014; López-Aguirre et al. 2017; Croft et al. 2018; Prevosti and Forasiepi 2018). The successful establishment of procyonids in South America was undoubtedly partly due to luck but perhaps principally due to the simple fact that these animals were entering a previously unoccupied ecological niche.

\section{Acknowledgments}

We thank L. H. Soibelzon for pictures of the lower dentition of Chapalmalania; M. J. Babot for pictures of Patene; R. M. D. Beck for useful discussions; J. Galkin and J. Meng (AMNH), W. Simpson and K. Angielczyk (FMNH), and M. Reguero (MLP) for access to specimens in their care; R. McCord (Arizona Museum of Natural History) for loans from the Larry Marshall Marsupial Dentition Collection; and J. Tarquini and two anonymous reviewers for comments that greatly improved this article.

\section{Literature Cited}

Alvarenga, H., L. Chiappe, and S. Bertelli. 2011. Phorusrhacids: the terror birds. Pp. 187-208 in G. Dyke and G. Kaiser, eds. Living dinosaurs: the evolutionary history of modern birds. Wiley, Oxford, U.K.

Ameghino, C., and J. Kraglievich. 1925. Un nuevo prociónido cercoleptoide en el Pampeano inferior de la Argentina, Brachynasua meranii, n. gen., n. sp. Comunicaciones Museo Nacional de Historia Natural, "Bernadino Rivadavia," Buenos Aires 2:181-191. 
Azzurro, E., V. M. Tuset, A. Lombarte, F. Maynou, D. Simberloff, A. Rodríguez-Pérez, and R. V. Solé. 2014. External morphology explains the success of biological invasions. Ecology Letters 17:1455-1463.

Baskin, J. A. 1982. Tertiary Procyoninae (Mammalia: Carnivora) of North America. Journal of Vertebrate Paleontology 2:71-93.

Baskin, J. A. 2003. New procyonines from the Hemingfordian and Barstovian of the Gulf Coast and Nevada, including the first fossil record of the Potosini. Bulletin of the American Museum of Natural History 279:125-146.

Baskin, J. A. 2004. Bassariscus and Probassariscus (Mammalia, Carnivora, Procyonidae) from the early Barstovian (middle Miocene). Journal of Vertebrate Paleontology 24:709-720.

Beck, R. M. D., and M. L. Taglioretti. 2019. A nearly complete juvenile skull of the marsupial Sparassocynus derivatus from the Pliocene of Argentina, the affinities of "sparassocynids," and the diversification of opossums (Marsupialia; Didelphimorphia; Didelphidae). Journal of Mammalian Evolution doi: 10.1007/ s10914-019-09471-y.

Berman, W. D. 1994. Los carnívoros continentales (Mammalia, Carnivora) del Cenozoico en la provincia de Buenos Aires. Universidad Nacional de La Plata, La Plata, Argentina.

Bigler, W. J., G. L. Hoff, and A. S. Johnson. 1981. Population characteristics of Procyon lotor marinus in estuarine mangrove swamps of southern Florida. Florida Scientist 44:151-157.

Burgin, C. J., J. P. Colella, P. L. Kahn, and N. S. Upham. 2018. How many species of mammals are there? Journal of Mammalogy 99:1-14.

Creel, S., and N. M. Creel. 1996. Limitation of African wild dogs by competition with larger carnivores. Conservation Biology 10:526-538.

Croft, D. A., R. K. Engelman, T. Dolgushina, and G. Wesley. 2018. Diversity and disparity of sparassodonts (Metatheria) reveal nonanalogue nature of ancient South American mammalian carnivore guilds. Proceedings of the Royal Society of London B 285:20172012. Cuaron, A. D., D. Valenzuela-Galvan, D. Garcia-Vasco, M. E. Copa, S. Bautista, H. Mena, D. Martinez-Godinez, C. Gonzalez-Baca, L. A. Bojorquez-Tapia, L. Barraza, P. C. Grammont, de, F. Galindo-Maldonado, M. A. Martinez-Morales, E. VazquezDominguez, E. Andresen, J. Benitez-Malvido, D. Perez-Salicrup, K. W. McFadden, and M. E. Gompper. 2009. Conservation of the endemic dwarf carnivores of Cozumel Island, Mexico. Small Carnivore Conservation 41:15-21.

Czaplewski, N. J. 1996. Opossums (Didelphidae) and bats (Noctilionidae and Molossidae) from the late Miocene of the Amazon Basin. Journal of Mammalogy 77:84-94.

Degrange, F. J., J. I. Noriega, and J. I. Areta. 2012. Diversity and paleobiology of Santacrucian birds. Pp. 138-155 in S. F. Vizcaíno, R. F. Kay, and M. S. Bargo, eds. Early Miocene paleobiology in Patagonia: high-latitude paleocommunities of the Santa Cruz Formation. Cambridge University Press, Cambridge.

Eizirik, E. 2012. A molecular view on the evolutionary history and biogeography of Neotropical carnivores (Mammalia, Carnivora). Pp. 123-142 in B. D. Patterson and L. P. Costa, eds. Bones, clones, and biomes. the history and geography of recent Neotropical mammals. University of Chicago Press, Chicago.

Engelman, R. K., and D. A. Croft. 2014. A new species of smallbodied sparassodont (Mammalia, Metatheria) from the middle Miocene locality of Quebrada Honda, Bolivia. Journal of Vertebrate Paleontology 34:672-688.

Flannery Sutherland, J. T., B. C. Moon, T. L. Stubbs, and M. J. Benton. 2019. Does exceptional preservation distort our view of disparity in the fossil record? Proceedings of the Royal Society of London B 286:20190091.

Fleagle, J. G., R. F. Kay, and M. R. L. Anthony. 1997. Fossil New World monkeys. Pp. 473-495 in R. F. Kay, R. H. Madden, R. L. Cifelli, and J. J. Flynn, eds. Vertebrate paleontology in the
Neotropics: the Miocene Fauna of La Venta, Colombia. Smithsonian Institution Press, Washington, D.C.

Flynn, J. J., J. Guerrero, and C. C. Swisher, III. 1997. Geochronology of the Honda Group. Pp. 44-59 in R. F. Kay, R. H. Madden, R. L. Cifelli, and J. J. Flynn, eds. Vertebrate paleontology in the Neotropics: the Miocene Fauna of La Venta, Colombia. Smithsonian Institution Press, Washington, DC.

Forasiepi, A. M., A. G. Martinelli, and F. J. Goin. 2007. Revisión taxonómica de Parahyaenodon argentinus Ameghino y sus implicancias en el conocimiento de los grandes mamíferos carnívoros del Mio-Plioceno de América de Sur. Ameghiniana 44:143-159.

Forasiepi, A. M., L. H. Soibelzon, C. S. Gomez, R. Sánchez, L. I. Quiroz, C. Jaramillo, and M. R. Sánchez-Villagra. 2014. Carnivorans at the Great American Biotic Interchange: new discoveries from the northern Neotropics. Naturwissenschaften 101:965-974.

Gingerich, P. D., and B. H. Smith. 1985. Allometric scaling in the dentition of primates and insectivores. Pp. 257-272 in W. L. Jungers, ed. Size and scaling in primate biology. Springer US, Boston, Mass.

Goin, F. J. 1997. New clues for understanding Neogene marsupial radiations. Pp. 187-206 in R. F. Kay, R. H. Madden, R. L. Cifelli, and J. J. Flynn, eds. Vertebrate paleontology in the Neotropics: the Miocene Fauna of La Venta, Colombia. Smithsonian Institution Press, Washington, D.C.

Gompper, M. E. 1997. Population ecology of the white-nosed coati (Nasua narica) on Barro Colorado Island, Panama. Journal of Zoology 241:441-455.

Hammer, Ø., D. A. T. Harper, and P. D. Ryan. 2001. PAST: paleontological statistics software package for education and data analysis. Palaeontologia Electronica 4:1-9.

Helgen, K. M., and D. E. Wilson. 2005. A systematic and zoogeographic overview of the raccoons of Mexico and Central America. Pp. 221-236 in V. Sánchez-Cordero and R. A. Medellín, eds. Contribuciones Mastozoologicas en Homenaje a Bernardo Villa. Instituto de Biología, Universidad Nacional Autónoma de México, Mexico City.

Hutchinson, G. E. 1959. Homage to Santa Rosalia or why are there so many kinds of animals? American Naturalist 93:145-159.

Kay, R. F. 1975. The functional adaptations of primate molar teeth. American Journal of Physical Anthropology 43:195-215.

Kay, R. F., R. H. Madden, R. L. Cifelli, and J. J. Flynn, eds. 1997. Vertebrate paleontology in the Neotropics: the Miocene Fauna of La Venta, Colombia. Smithsonian Institution Press, Washington, D.C. Koepfli, K.-P., M. E. Gompper, E. Eizirik, C.-C. Ho, L. Linden, J. E. Maldonado, and R. K. Wayne. 2007. Phylogeny of the Procyonidae (Mammalia: Carnivora): molecules, morphology and the Great American Interchange. Molecular Phylogenetics and Evolution 43:1076-1095.

Kraglievich, J. L., and A. G. de Olazabal. 1959. Los prociónidos extinguidos del género Chapalmalania Amegh. Revista del Museo Argentino de Ciencias Naturales, Ciencias Zoologícas $6: 1-59$.

Lindqvist, C., S. C. Schuster, Y. Sun, S. L. Talbot, J. Qi, A. Ratan, L. P. Tomsho, L. Kasson, E. Zeyl, J. Aars, W. Miller, Ó. Ingólfsson, L. Bachmann, and Ø. Wiig. 2010. Complete mitochondrial genome of a Pleistocene jawbone unveils the origin of polar bear. Proceedings of the National Academy of Sciences USA 107:5053-5057

Linnell, J. D. C., and O. Strand. 2000. Interference interactions, co-existence and conservation of mammalian carnivores. Diversity and Distributions 6:169-176.

López-Aguirre, C., M. Archer, S. J. Hand, and S. W. Laffan. 2017. Extinction of South American sparassodontans (Metatheria): environmental fluctuations or complex ecological processes? Palaeontology 60:91-115. 
Lyras, G. A., A. A. E. van der Geer, and L. Rook. 2010. Body size of insular carnivores: evidence from the fossil record. Journal of Biogeography 37:1007-1021.

Marshall, L. G. 1976. Evolution of the Thylacosmilidae, extinct saber-tooth marsupials of South America. Paleobios 23:1-30.

Marshall, L. G. 1977. Evolution of the carnivorous adaptive zone in South America. Pp. 709-721 in M. K. Hecht, P. C. Goody, and B. M. Hecht, eds. Major patterns in vertebrate evolution. Plenum, New York.

Marshall, L. G. 1978. Evolution of the Borhyaenidae, extinct South American predaceous marsupials. University of California Publications in Geological Sciences 117:1-89.

Marshall, L. G. 1979. Review of the Prothylacyninae, an extinct subfamily of South American "dog-like" marsupials. Fieldiana (Geology), new series 3:1-49.

Marshall, L. G. 1981. The Great American Interchange: an invasion induced crisis for South American mammals. Pp. 133-229 in M. H. Nitecki, ed. Biotic crises in ecological and evolutionary time. Academic Press, New York.

Marshall, L. G., R. F. Butler, R. E. Drake, G. H. Curtis, and R. H. Tedford. 1979. Calibration of the Great American Interchange. Science 204:272-279.

McFadden, K. W., M. E. Gompper, D. G. Valenzuela, and J. C. Morales. 2008. Evolutionary history of the critically endangered Cozumel dwarf carnivores inferred from mitochondrial DNA analyses. Journal of Zoology 276:176-186.

Meiri, S., T. Dayan, and D. Simberloff. 2004. Body size of insular carnivores: little support for the island rule. American Naturalist 163:469-479.

Mitchell, K. J., S. C. Bray, P. Bover, L. Soibelzon, B. W. Schubert, F. Prevosti, A. Prieto, F. Martin, J. J. Austin, and A. Cooper. 2016. Ancient mitochondrial DNA reveals convergent evolution of giant short-faced bears (Tremarctinae) in North and South America. Biology Letters 12:20160062.

Montes, C., A. Cardona, C. Jaramillo, A. Pardo, J. C. Silva, V. Valencia, C. Ayala, L. C. Pérez-Angel, L. A. Rodriguez-Parra, V. Ramirez, and H. Niño. 2015. Middle Miocene closure of the Central American Seaway. Science 348:226-229.

O'Dea, A., H. A. Lessios, A. G. Coates, R. I. Eytan, S A. Restrepo-Moreno, A. L. Cione, L. S. Collins, A. de Queiroz, D. W. Farris, R. D. Norris, R. F. Stallard, M. O. Woodburne, O. Aguilera, M.-P. Aubry, W. A. Berggren, A. F. Budd, M. A. Cozzuol, S. E. Coppard, H. Duque-Caro, S. Finnegan, G. M. Gasparini, E. L. Grossman, K. G. Johnson, L. D. Keigwin, N. Knowlton, E. G. Leigh, J. S. Leonard-Pingel, P. B. Marko, N. D. Pyenson, P. G. Rachello-Dolmen, E. Soibelzon, L. Soibelzon, J. A. Todd, G. J. Vermeij, and J. B. C. Jackson. 2016. Formation of the Isthmus of Panama. Science Advances 2:e1600883.

Oldfield, C. C., C. R. McHenry, P. D. Clausen, U. Chamoli, W. C. H. Parr, D. D. Stynder, and S. Wroe. 2011. Finite element analysis of ursid cranial mechanics and the prediction of feeding behaviour in the extinct giant Agriotherium africanum. Journal of Zoology 286:163-170.

Orcutt, J. D. 2015. Ecomorphology of Australian carnivore guilds. Journal of Vertebrate Paleontology, Program and Abstracts, p. 190.

Ortiz-Ramírez, M. F., L. A. Sánchez-González, G. CastellanosMorales, J. F. Ornelas, and A. G. Navarro-Sigüenza. 2018. Concerted Pleistocene dispersal and genetic differentiation in passerine birds from the Tres Marías Archipelago, Mexico. The Auk 135:716-732.

Palomares, F., and T. M. Caro. 1999. Interspecific killing among mammalian carnivores. American Naturalist 153:492-508.

Patterson, B., and R. Pascual. 1968. The fossil mammal fauna of South America. Quarterly Review of Biology 43:409-451.

Pearson, D. E., Y. K. Ortega, and S. J. Sears. 2012. Darwin's naturalization hypothesis up-close: intermountain grassland invaders differ morphologically and phenologically from native community dominants. Biological Invasions 14:901-913.

Pol, D., J. M. Leardi, A. Lecuona, and M. Krause. 2012. Postcranial anatomy of Sebecus icaeorhinus (Crocodyliformes, Sebecidae) from the Eocene of Patagonia. Journal of Vertebrate Paleontology 32:328-354.

Prevosti, F. J., A. Forasiepi, and N. Zimicz. 2013. The evolution of the Cenozoic terrestrial mammal guild in South America: competition or replacement? Journal of Mammalian Evolution 20:3-21.

Prevosti, F. J., and A. M. Forasiepi. 2018. Evolution of South American mammalian predators during the Cenozoic: palaeobiogeographic and palaeoenvironmental contengencies. Springer, Cham, Switzerland.

Prothero, D. R., K. E. Campbell, B. L. Beatty, and C. D. Frailey. 2014. New late Miocene dromomerycine artiodactyl from the Amazon Basin: implications for interchange dynamics. Journal of Paleontology 88:434-443.

Reguero, M. A., and A. M. Candela. 2011. Late Cenozoic mammals from the northwest of Argentina. Pp. 411-426 in J. A. Salfity and R. A. Marquillas, eds. Cenozoic geology of the Central Andes of Argentina. SCS Publisher, Salta, Argentina.

Reyes, M. d. 1., D. Poiré, L. Soibelzon, A. E. Zurita, and M. J. Arrouy. 2013. First evidence of scavenging of a glyptodont (Mammalia, Glyptodontidae) from the Pliocene of the Pampean region (Argentina): taphonomic and paleoecological remarks. Palaeontologia Electronica 16:15A: 1-13.

Rick, T. C., J. M. Erlandson, R. L. Vellanoweth, T. J. Braje, P. W. Collins, D. A. Guthrie, and T. W. Stafford. 2009. Origins and antiquity of the island fox (Urocyon littoralis) on California's Channel Islands. Quaternary Research 71:93-98.

Riggs, E. S. 1934. A new marsupial saber-tooth from the Pliocene of Argentina and its relationships to other South American predacious marsupials. Transactions of the American Philosophical Society 24:1-32.

Robinson, J. G., and K. H. Redford. 1986. Body size, diet, and population density of Neotropical forest mammals. American Naturalist 128:665-680.

Rodriguez, S. G., L. H. Soibelzon, S. Rodrigues, C. C. Morgan, C. Bernardes, L. Avilla, and E. Lynch. 2013. First record of Procyon cancrivorus (G. Cuvier, 1798) (Carnivora, Procyonidae) in stratigraphic context in the Late Pleistocene of Brazil. Journal of South American Earth Sciences 45:1-5.

Ruiz-Ramoni, D., A. Rincón, and M. Montellano-Ballesteros. 2019. Evidencias del origen de Nasua y Procyon (Procyonidae: Carnivora) en América del Sur. Revista Brasileira de Paleontologia 21:87-94.

Sacco, T., and B. Van Valkenburgh 2004. Ecomorphological indicators of feeding behaviour in the bears (Carnivora: Ursidae). Journal of Zoology 263:41-54.

Scapino, R. 1981. Morphological investigation into functions of the jaw symphysis in carnivorans. Journal of Morphology 167:33975.

Scott, J. E., A. S. Hogue, and M. J. Ravosa. 2012. The adaptive significance of mandibular symphyseal fusion in mammals. Journal of Evolutionary Biology 25:661-673.

Sih, A., D. I. Bolnick, B. Luttbeg, J. L. Orrock, S. D. Peacor, L. M. Pintor, E. Preisser, J. S. Rehage, and J. R. Vonesh. 2010. Predator-prey naïveté, antipredator behavior, and the ecology of predator invasions. Oikos 119:610-621.

Simpson, G. G. 1950. History of the fauna of Latin America. American Scientist 38:361-389.

Simpson, G. G. 1980. Splendid isolation: the curious history of South American mammals. Yale University Press, New Haven, Conn.

Skóra, F., V. Abilhoa, A. A. Padial, and J. R. S. Vitule. 2015. Darwin's hypotheses to explain colonization trends: evidence from 
a quasi-natural experiment and a new conceptual model. Diversity and Distributions 21:583-594.

Soibelzon, E., G. M. Gasparini, A. E. Zurita, and L. H. Soibelzon. 2008. Análisis faunístico de vertebrados de las toscas del Río de La Plata (Buenos Aires, Argentina): un yacimiento paleontológico en desaparición. Revista del Museo Argentino de Ciencias Naturales 10:291-308.

Soibelzon, L., and F. J. Prevosti. 2007. Los carnívoros (Carnivora, Mammalia) terrestres del Cuaternario de América del Sur. Pp. 49-68 in G. X. Pons and D. Vicens, eds. Geomorfología Litoral i Quaternari. Homenatge a Joan Cuerda Barceló. Monografia de la Societat d'Història Natural, Palma de Mallorca.

Soibelzon, L. H. 2011. First description of milk teeth of fossil South American procyonid from the lower Chapadmalalan (Late Miocene-Early Pliocene) of "Farola Monte Hermoso," Argentina: paleoecological considerations. Paläontologische Zeitschrift 85:83-89.

Soibelzon, L. H., A. Rinderknecht, J. Tarquini, and R. Ugalde. 2019. First record of fossil procyonid (Mammalia, Carnivora) from Uruguay. Journal of South American Earth Sciences 92:368-373.

Strait, S. G. 1993. Differences in occlusal morphology and molar size in frugivores and faunivores. Journal of Human Evolution 25:471-484.

Tambussi, C. P., and F. J. Degrange. 2013. The dominance of zoophagous birds: just a cliché? Pp. 87-102 in C. P. Tambussi and F. Degrange, eds. South American and Antarctic continental Cenozoic birds: paleobiogeographic affinities and disparities. Springer, Dordrecht, Netherlands.

Tarquini, J., N. Toledo, C. C. Morgan, and L. H. Soibelzon. 2017. The forelimb of $\uparrow$ Cyonasua sp. (Procyonidae, Carnivora): ecomorphological interpretation in the context of carnivorans. Earth and Environmental Science Transactions of the Royal Society of Edinburgh 106:325-335.

Tarquini, J., N. Toledo, L. H. Soibelzon, and C. C. Morgan. 2018a. Body mass estimation for $†$ Cyonasua (Procyonidae, Carnivora) and related taxa based on postcranial skeleton. Historical Biology 30:496-506.

Tarquini, J., M. G. Vilchez Barral, and L. H. Soibelzon. 2016. Los prociónidos fósiles de América del Sur. Pp. 359-365 in F. L. Agnolin, G. L. Lio, F. Brissón Egli, N. R. Chimento, and F. E. Novas, eds. Historia Evolutiva y Paleobiogeográfica de los Vertebrados de América del Sur. Museo Argentino de Ciencias Naturalis "Bernardino Rivadavia," Buenos Aires.

Tarquini, S. D., M. A. Chemisquy, and F. J. Prevosti. 2018b. Evolution of the carnassial in living mammalian carnivores (Carnivora, Didelphimorphia, Dasyuromorphia): Diet, phylogeny, and allometry. Journal of Mammalian Evolution. doi: 10.1007/s10914-018-9448-7.
Van der Geer, A. G., Lyras, J. Vos de, and M. Dermitzakis. 2011. Evolution of island mammals: adaptation and extinction of placental mammals on islands. Wiley-Blackwell, Chichester, U.K.

Van Valkenburgh, B. 1990. Skeletal and dental predictors of body mass in carnivores. Pp. 181-205 in J. Damuth and B. J. MacFadden, eds. Body size in mammalian paleobiology: estimation and biological implications. Cambridge University Press, Cambridge.

Van Valkenburgh, B. 1991. Iterative evolution of hypercarnivory in canids (Mammalia: Carnivora): evolutionary interactions among sympatric predators. Paleobiology 17:340-362.

Vidal-García, M., and J. S. Keogh. 2017. Invasive cane toads are unique in shape but overlap in ecological niche compared to Australian native frogs. Ecology and Evolution 7:7609-7619.

Vizcaíno, S. F., and G. De Iuliis. 2003. Evidence for advanced carnivory in fossil armadillos (Mammalia: Xenarthra: Dasypodidae). Paleobiology 29:123-138.

Vizcaíno, S. F., R. A. Fariña, M. A. Zárate, M. S. Bargo, and P. Schultz. 2004. Palaeoecological implications of the mid-Pliocene faunal turnover in the Pampean Region (Argentina). Palaeogeography, Palaeoclimatology, Palaeoecology 213:101-113.

Webb, S. D. 1985. Late Cenozoic mammal dispersals between the Americas. Pp. 357-386 in F. G. Stehli and S. D. Webb, eds. The Great American Biotic Interchange. Springer US, Boston, Mass.

Werdelin, L. 1987. Jaw geometry and molar morphology in marsupial carnivores; analysis of a constraint and its macroevolutionary consequences. Paleobiology 13:342-350.

Werdelin, L., and M. E. Lewis. 2013. Temporal change in functional richness and evenness in the eastern African Plio-Pleistocene carnivoran guild. PLoS ONE 8:e57944.

Werdelin, L., and G. D. Wesley-Hunt. 2010. The biogeography of carnivore evolution. Pp. 225-245 in A. Goswami and A. Friscia, eds. Carnivoran evolution: new views on phylogeny, form, and function. Cambridge University Press, Cambridge.

Wesley-Hunt, G. D. 2005. The morphological diversification of carnivores in North America. Paleobiology 31:35-55.

Woodburne, M. O. 2010. The Great American Biotic Interchange: dispersals, tectonics, climate, sea level and holding pens. Journal of Mammalian Evolution 17:245-264.

Wroe, S., C. Argot, and C. Dickman. 2004. On the rarity of big fierce carnivores and primacy of isolation and area: tracking large mammalian carnivore diversity on two isolated continents. Proceedings of the Royal Society of London B 271:1203-1211.

Zeveloff, S. I. 2002. Raccoons: a natural history. Smithsonian Institution Press, Washington, D.C.

Zimicz, N. 2014. Avoiding competition: the ecological history of late Cenozoic metatherian carnivores in South America. Journal of Mammalian Evolution 21:383-393. 